Dariusz Jarosz

Warszawa

\title{
Książki pod strzechy \\ Z badań nad politycznymi uwikłaniami czytelnictwa na wsi polskiej w latach 1949-1956
}

Jednym $z$ kanonicznych elementów oficjalnych wystapień peerelowskich ludzi władzy, opisujących zasługi Polski Ludowej, było stwierdzenie o upowszechnieniu czytelnictwa i przezwyciężeniu niechlubnego spadku rządów sanacyjnych $\mathrm{w}$ postaci plagi analfabetyzmu. Dowodzić tego miały imponujące wskaźniki wzrostu liczby bibliotek, księgozbiorów i czytelników. Jako szczególnie istotny uznawano przebieg tych procesów na wsi jako tradycyjnie zaniedbanej i cywilizacyjnie, nie ze swej winy, zapóźnionej.

Tymczasem głębszy opis tych zjawisk, oparty o różnorodny materiał źródłowy pokazuje różnorodne polityczne uwikłania tego procesu, które szczególnie mocno odcisnęly piętno na jego przebiegu w okresie stalinizmu. Spróbujmy odpowiedzieć na pytanie, czym miała być książka i czytelnictwo w modelu komunistycznej polityki kulturalnej w latach 1949-1956, a następnie - jakie były bariery jego realizacji na wsi, co o nim sądzili i jak nań reagowali sami zainteresowani.

\section{Książka i czytelnictwo wiejskie w stalinowskim „świecie przedstawień”}

Książka, tak jak literatura i kultura w ogóle, była wówczas traktowana przede wszystkim jako oręż propagandy i agitacji. W przypadku wsi oznaczało to używanie jej jako sposobu propagowania tych elementów polityki władz, które były adresowane do chłopów. $Z$ tego punktu widzenia najwyżej oceniane były dzieła propagujące walkę $z$ licznymi wrogami „władzy ludowej”, w tym przede wszystkim $z$ „kułakiem”, kolektywizację rolnictwa i realizację obowiązkowych dostaw płodów rolnych ${ }^{1}$.

\footnotetext{
${ }^{1}$ Na ten temat - zob. m.in. A. Dobieszewski, Kolektywizacja wsi polskiej 1948-1956, Warszawa 1993; K. Robakowski, Społeczno-polityczne problemy rozwoju spółdzielczości produkcyjnej w Polsce w latach 1944-1956, Poznań 1986; J. Kaliński, Forsowna kolektywizacja rolnictwa (1948-1956), „Kwartalnik Historyczny”, 1984, nr 1; A. Korboński, Politics of Socialist Agriculture in Poland: 1945-1960, Columbia University Press, New York-London 1965; H. Słabek, Niektóre właściwości ruchu spółdzielczości pro-
} 
Z tego powodu w wytycznych Zarządu Głównego Związku Samopomocy Chłopskiej (ZSCh) na rok 1950 stwierdzano: „Podstawowym założeniem naszej pracy kulturalno-oświatowej jest mobilizacja mas mało i średniorolnych chłopów na bazie walki klasowej do realizacji planu sześcioletniego jako budowy podstaw ustroju socjalistycznego”. W tym celu „będziemy stale i uporczywie walczyć aż do pełnego wyeliminowania wpływów wrogich nam elementów na wsi, kułaków, spekulantów i rozpolitykowanych, reakcyjnych księży [...]”. Instytucje kulturalne miały stać się ,jednym z czynników aktywizujących i przygotowujących [...] do przejścia do gospodarki socjalistycznej”2. Nieprzypadkowo równiė̇ Jakub Berman - członek Biura Politycznego KC PZPR, odpowiedzialny za ideologię i propagandę, w październiku 1951 r., w trakcie narady poświęconej twórczości artystycznej nawoływał zgromadzonych na niej ludzi kultury: „Dosięgnijcie waszą ostrą bronią kułaka i spekulanta, szpiega, dywersanta, amerykańskiego podżegacza i neohitlerowca. Odsłońcie zawiły mechanizm kułackiej postawy, kułackiego wyzysku, jego perfidne zasłanianie się chłopem mało i średniorolnym. Ukażcie całą ostrość przeciwieństw, pokażcie wielkość naszych czasów"3. Aby ułatwić pisarzom realizację tych postulatów organizowano akcje ich wyjazdów na wieś, gdzie naocznie mieli się zmierzyć z problemami „walki klasowej”4.

Realizacji zadań stalinowskiej polityki rolnej podporządkowane zostały występy artystyczne na wsi $z$ udziałem ówczesnych satyryków, realizowane w strukturach organizacyjnych Państwowej Organizacji Imprez Artystycznych „Artos”. Jak ustaliła Iwona Miernik w maju 1953 r. ukazał się specjalny okólnik, podpisany przez wicedyrektora tej organizacji, w którym stwierdzano: „Zadaniem «ARTOS»-u w roku bieżącym, zgodnie $z$ uchwałami Komitetu Centralnego Polskiej Zjednoczonej Partii Robotniczej oraz Kolegium Ministerstwa Kultury i Sztuki jest jak najszersze rozwinięcie akcji wiejskiej”. Przypominano, że należy zwrócić uwage na dobór odpowiednich kadr do zespołów wiejskich. Ich członkowie „powinni sobie bardzo dokładnie zdawać sprawę $z$ roli politycznej, jaką mają do wykonania w terenie. Akcję uświadomienia roli aktora zespołu wiejskiego należy przedsięwziąć w porozumieniu $z$ miejscowymi czynnikami partyjnymi i związkowymi”. Przy innej okazji dyrektor Centralnego Zarządu Teatrów, Oper i Filharmonii w Ministerstwie Kultury i Sztuki, Jerzy Pański twierdził, że „Jeśli nie pójdziemy na wieś $z$ programem paraliżującym działalność wroga klasowego, to nie spełnimy zadania. Musimy wmontować w imprezy ostry materiał polityczny i z nim docierać na wieś”.

dukcyjnej (1949-1953), „Roczniki Dziejów Ruchu Ludowego”, 1981, nr 21; tenże, Powikłania polskiej kolektywizacji rolnictwa (1954-1956), „Dzieje Najnowsze”, 1986, z. 1; D. Jarosz, Ze słownika propagandy stalinowskiej: „K” jak „,kułak”, „Mówią Wieki” 1990, nr 12, s. 1-5, tenże, Polityka władz komunistycznych w Polsce w latach 1948-1956 a chłopi, Warszawa 1998.

${ }^{2}$ Archiwum Akt Nowych (dalej: AAN), Zarząd Główny Związku Samopomocy Chłopskiej (dalej: ZG ZSCh), 1336, Wytyczne i zalecenia pracy kulturalno-oświatowej na rok 1950.

${ }^{3}$ Narada poświęcona twórczości artystycznej 27 X-28 X, „Twórczość” 1951, nr 12.

${ }^{4}$ Zob. m.in. Tadeusz Drewnowski, Tyle hałasu o nic?, Warszawa 1982, s. 118.

5 Analiza i cytaty za: I. Miernik, Państwowa Organizacja Imprez Artystycznych „ARTOS” 19501954. Monografia historyczna, Toruń 2005, s. 102. 
Nawiązanie stałego kontaktu $z$ chłopami miało przybierać różne formy. Zalecano ustalanie patronatów zespołów „ARTOS”-u nad wytypowanymi wsiami. Przy ich wyborze „należy mieć na uwadze przede wszystkim te miejscowości, które są najbardziej zaniedbane pod względem kulturalnym. Do zadań zespołu, który obejmie patronat nad wsią, należeć będzie stała opieka artystyczna [...], wyrażająca się w tego rodzaju pracach jak organizacja i stała opieka nad świetlicą, nad zespołami amatorskimi, rozwijanie zmysłu estetyki itd.”. Inną formą wzajemnego zbliżenia miała być opieka nad świetlicami i zespołami amatorskimi w czasie pobytu ekipy artystów w danej wsi (pomoc reżyserska, dostarczanie odpowiednich tekstów itp. $)^{6}$.

Przekonanie o tym, ze odpowiednio kierowana działalność kulturalna, w tym „właściwie” dobrana literatura może stymulować pożądane przemiany społeczno-gospodarcze na wsi i zmienić mentalność chłopów było stałym elementem ówczesnej publicystyki. Oto jeden $z$ bohaterów reportażu, zamieszczonego w tygodniku „Wieś” w 1954 r. po przeczytaniu powieści radzieckiego pisarza Michaiła Panfierowa „Bruski” miał wstapić do spółdzielni produkcyjnej i partii, gdyż „Ciasno mu było w jego zagrodzie, ciasno na ziemi, obramowanej czerniejąca na śniegu granicą”. W innym przypadku wiejska bibliotekarka, odpowiednio dobierając lekturę swych wiejskich czytelników, miała ich doprowadzić do decyzji o założeniu zespołowej gospodarki ${ }^{8}$.

„Klasowa” wizja podziałów społecznych na wsi („kułacy”, „średniacy”, „,biedniacy”) odciskała swe piętno również na propagandowej wizji wiejskiego czytelnictwa. Zgodnie $z$ nią miało się ono rozwijać ze szczególną intensywnością we wsiach biedniejszych. To klasowo bliski „władzy ludowej” biedniak miał przez lekturę poszukiwać dróg wyzwolenia $z$ nędzy i upośledzenia. Chłop bogaty, jeżeli kiedykolwiek miał czas na czytanie, czynił to tylko dlatego, że podobała mu się jakaś scena lub „wątek erotyczny”. Nowy wiejski czytelnik, miał być zainteresowany lekturą głównie ze względów praktycznych, poznawczych, a mniej estetycznych, co uznawano za zjawisko ze wszech miar pożądane. W tej wizji ogromną rolę przypisywano bibliotekarzowi, którego zadaniem było podsuwanie najciekawszych książek, dzięki którym następowały przemiany chłopskiej mentalności i postępował proces tworzenia „nowego człowieka” ${ }^{\text {. }}$.

Integralnym elementem tych politycznych koncepcji, dotyczących roli książki i czytelnictwa była walka $z$ analfabetyzmem, która przybrała formę kampanii, rozpoczętej na podstawie ustawy sejmowej z 7 kwietnia 1949 r. Z punktu widzenia podjętych rozważań istotna wydaje się odpowiedź na pytanie, jakie cele przyświecały jej organizatorom. Wydaje się, że pod tym względem wielce symptomatyczna była wypowiedź prezesa Rady Ministrów, Józefa Cyrankiewicza, na

\footnotetext{
${ }^{6}$ Ibidem, s. 103.

${ }^{7}$ T. Jasiński, Droga Cyryla Żdarkina, „Wieś” 1954, nr 10.

${ }^{8}$ B. Góralik-Bażanowski, Z książka do lepszego życia, „Zielony Sztandar” 1953, nr 20.

${ }^{9}$ K. Bartyzel, Chłop biedny czyta więcej od zamożnego, „Wieś” 1950, nr 30; G. Tomala, Na terenie pewnej gminy..., „Wieś” 1949, nr 8.

${ }^{10}$ M. Bielawski, W trosce o przyszłość bibliotek gminnych, „Nowa Kultura” 1951, nr 26.
} 
odprawie sekretarzy Komitetów Wojewódzkich PZPR 10 marca 1949 r. Twierdził, że akcja ta została podjęta „Zarówno ze względu na plan sześcioletni, jak i ze względu na bardzo prosty fakt, że analfabeci są i nie przestaną być podstawową bazą reakcji, w szczególności kleru, podczas gdy my chcemy $z$ wyzwolonych analfabetów uczynić jeden $z$ bardzo ważnych czynników realizacji planu sześcioletniego nie mówiąc już o innych politycznych i społecznych korzyściach wyzwolenia tak dużej ilości analfabetów"11. W wypowiedzi premiera charakterystyczne jest owo rozłożenie akcentów przy formułowaniu celów akcji. Kampania na rzecz likwidacji analfabetyzmu miała być w intencjach władz przede wszystkim przedsięwzięciem o charakterze ideologiczno-politycznym.

Ten sam w istocie rzeczy typ argumentacji występował w oficjalnych wystąpieniach innych decydentów, odpowiedzialnych za przebieg tej kampanii. Oto np. Pełnomocnik Rządu do Walki z Analfabetyzmem Stefan Matuszewski na jednej z narad zorganizowanych w Katowicach w 1950 r. twierdził: „Fakt, że coraz bardziej do szerokich kół przenika dobra książka, książka ze słusznym marksistowskim poglądem na świat i życie, że ludzie coraz więcej wnikają w naukowe zasady, nie ulegając bałamutnym podszeptom, że książka i gazeta stają się codzienną pożywką wszystkich ludzi pracujących, to wielkie nasze osiągnięcie i duży wkład w rozwój społeczeństwa, a więc siłą rzeczy i wkład w walkę o pokój. Jest rzeczą jasną, iż aby korzystać z ksiązki i prasy potrzebna jest znajomość i umiejętność pisania i czytania”12.

W ówczesnej prasie cytowano liczne wypowiedzi byłych analfabetów, którzy już w trakcie nauki czytania i pisania, dzięki „właściwie” dobranej literaturze poznawali „abecadło polityczne”, uczyli się rozróżniać „wroga klasowego”13. Wyrażali równiė̇ wdzięczność Polsce Ludowej za opiekę nad nimi. W standardowym tekście zbiorowego listu byłych analfabetów, uczestnicy kursu w Boleściwie w powiecie trzebnickim pisali: „Aby wysiłek naszych nauczycieli włożony w pracę nad nami nie poszedł na marne, postanawiamy pracować stale i wytrwale nad sobą. Iść dalej i dalej, podążając za wszystkimi, żyć szczęściem mas pracujących w naszej Odrodzonej Ojczyźnie, dążyć do budowy nowej Polski Socjalistycznej” ${ }^{14}$.

Zwalczanie analfabetyzmu było równiė̇ tematem prostych montaży słownomuzycznych, które miały być wykorzystywane przez członków amatorskich zespołów artystycznych w celach propagandowych. W jednym $z$ nich, autorstwa Jana Cholewskiego, posługiwano się okolicznościową piosenką zawierającą następujące słowa: „Otwórzcie drzwi na ościė̇ - Bo idą do was goście Wyciągnij dłoń i sięgaj - po wiedzę co jest w księgach - Książka ci otworzy oczy

${ }^{11}$ AAN, Komitet Centralny Polskiej Zjednoczonej Partii Robotniczej (dalej: KC PZPR), 237/V-17, Stenogram odprawy sekretarzy wojewódzkich PZPR w dniu 10 III 1949, s. 69-74.

${ }^{12}$ Jeszcze jedna zwycięska batalia na froncie walki z analfabetyzmem, „Dziennik Zachodni”, 1950, nr 67.

${ }^{13}$ Zob. m.in. T. Papier, Dwa abecadła, „Wieś”, 1950, nr 37; F. Nienaski, Umiemy już czytać, „Chłopska Droga”, 1949, nr 19.

${ }^{14}$ Likwidacja analfabetyzmu w gromadach dolnoślaskich, „Gazeta Robotnicza”, 1950, nr 122. 
- Powie gdzie brat gdzie wróg - choć wczoraj obca ci może - dziś przyszła pod twój próg - choć takie zwykłe karty - w tych kartach świat otwarty - i światła coraz więcej - wyciągnij tylko ręce - Gdy w książki karty patrzysz - toś co dzień jest bogatszy - dobrobyt $z$ wiedzą w parze - od książki bierzesz w darze"15.

Walka $z$ analfabetyzmem była ważnym elementem działalności wielu organizacji społecznych, w tym Związku Młodzieży Polskiej (ZMP) ${ }^{16}$. Oto „Trybuna Robotnicza” w czerwcu 1951 r. pisała o inicjatywie członków organizacji - uczniów gimnazjum: Janiny Jackowskiej i Ryszarda Bera oraz studenta prawa na Uniwersytecie Warszawskim - Henryka Jackowskiego, którzy „rzucili młodzie$\dot{z y}$ hasło nauczania indywidualnego analfabetów w czasie wakacji - tzw. wakacyjnego czynu młodzieży. [...] W tegorocznych wakacjach nie będzie ucznia ZMP-owca, który by nie nauczył indywidualnie jednego analfabety"17. Hasło współzawodnictwa w walce $z$ analfabetyzmem „rzucone” przez zarząd Wojewódzki ZMP w Poznaniu przekształciło się w 1950 r. w rutynowe zadanie wszystkich struktur organizacji ${ }^{18}$. W marcu 1950 r. „Opolski Dziennik Zachodni” informował: „Powiatowy Zarząd Związku Młodzieży Polskiej złożył ostatnio w Inspektoracie Szkolnym w Opolu zobowiązanie czynnego udziału w likwidacji analfabetyzmu w mieście i powiecie. W szczególności ZMP przyrzeka usprawnić i spotęgować walkę $z$ analfabetyzmem w wioskach, wykazujących dotąd na ogół słabe wyniki, jak: Daniec, Dobrzeń Wielki, Gosławice, Czarnowąsy, Proszowice, Dąbrówka Dolna, Domecko, Zużela, Prószków, Miedziany Tarnowskie, Pokój i Murów"19.

W kampanii tej uczestniczyły również struktury organizacyjne Ligii Kobiet. Prasa ówczesna pisała o współzawodnictwie w zakresie szkolenia indywidualnego analfabetów, zainicjowanym przez tę organizację, do którego wezwano ZMP i $\mathrm{ZSCh}^{20}$.

O jednoznacznie określonym kierunku, jaki nadano nie tylko walce $z$ analfabetyzmem, ale - szerzej - upowszechnianiu czytelnictwa świadczy również zestaw lektur, obowiązujących w organizowanych od 1951 r. przez ZG ZSCh konkursach czytelników bibliotek wiejskich. W trzech pierwszych blokach tematycznych zatytułowanych: „Jak było dawniej”, „Za Waszą i Naszą Wolność” oraz „Budowa podstaw socjalizmu w Polsce Ludowej” proponowano wykorzystać 30 książek. Z klasycznych dzieł polskiej beletrystyki znalazły się wśród nich

\footnotetext{
${ }^{15}$ AAN, Biuro Pełnomocnika Rządu do Walki z Analfabetyzmem (dalej: BPRdWA), 61, „Nauka to potęgi klucz”, k. 100.

${ }^{16}$ AAN, BPRdWA, 57, Uchwała Sekretariatu Zarządu Głównego Związku Młodziė̇y Polskiej o zadaniach ZMP w likwidacji analfabetyzmu [styczeń 1951], k. 240-246.

${ }^{17}$ Cała młodzież polska włączy się do akcji likwidacji analfabetyzmu, „Trybuna Robotnicza” 1950, nr 169.

${ }^{18}$ ZMP-owcy Dolnego Śląska szkoła analfabetów, „Trybuna Ludu” 1950, nr 87.

${ }^{19}$ ZMP w Opolu przyrzeka pomoc w likwidacji analfabetyzmu, „Opolski Dziennik Zachodni” 1950, nr 63.

${ }^{20}$ Zob. m.in.: Śląskie aktywistki LK opiekują się kursami dla analfabetów, „Dziennik Zachodni” 1950, nr 7.
} 
utwory Marii Konopnickiej („Dym”), Bolesława Prusa („Powracająca fala” i „Antek”) i Henryka Sienkiewicza (,Janko Muzykant”). Z dzieł klasyki radzieckiej polecano: „Matkę” Maksyma Gorkiego, „Opowieść o prawdziwym człowieku” Borysa Polewoja, „W okopach Stalingradu” Wiktora Niekrasowa, „Szosę Wołokołamską” Aleksandra Beka, „Młodą Gwardię” Aleksandra Fadiejewa, „Szczęście żołnierskie” Wadima Kożewnikowa. Ponadto na liście tych lektur znalazły się „Światła w Koordi” Hansa Leberechta. Z dzieł polskiego socrealizmu wśród zalecanych lektur wymieniono: „Nr 16 produkuje” Jana Wilczka i „Stasiek Kaługa staje do współzawodnictwa” Aleksandra Ścibora-Rylskiego. Zestaw uzupełniały utwory literackie Władysława Kowalskiego („W Grzmiącej”) i Wandy Wasilewskiej („Ojczyzna” i „Na poddaszu”). Ponadto niedawni analfabeci mieli czytać artykuły prasowe (głównie $z$ „Gromady”), dotyczące konstytucji, popularne, częściowo fabualryzowane biografie Małgorzaty Fornalskiej i Karola Świerczewskiego oraz proste reportaże. W czwartym bloku tematycznym znalazły się popularne opracowania $z$ zakresu gospodarki rolnej ${ }^{21}$. Zestaw tych lektur w kolejnych etapach konkursu się zmieniał, ale ich funkcje i cele, które zamierzano osiąnąć formułowane były podobnie. W przygotowywanym na posiedzenie Prezydium ZG ZSCh 30 września 1953 r. projekcie uchwały, podsumowującej trzy etapy konkursu stwierdzano wszak, że „Czytelnictwo postępowych książek, dyskutowanie nad ich treścią i wyciąganie wniosków stanowi skuteczny środek do pogłębienia świadomości politycznej pracujących chłopów, podnoszenia ich sprawności w rozwijaniu gospodarki i ugruntowania ich patriotycznej postawy w wykonywaniu obowiązków wobec państwa"22.

Kampanijny i jednoznacznie zorientowany politycznie sposób myślenia o czytelnictwie znalazł wówczas ujście równiė̇ w cyklicznie organizowanych imprezach, od 1951 r. nazwanych Dniami (wcześniej Dekada) Oświaty, Książki i Prasy. W instrukcji podpisanej 16 kwietnia 1951 r. przez przewodniczącego Głównego Komitetu Obywatelskiego tych Dni - premiera J. Cyrankiewicza - czytamy, że przebiegać one miały (od 3 do 15 maja) w okresie „wielkiej ofensywy sił pokoju” na całym świecie, w okresie przygotowań do narodowego plebiscytu pokoju w kraju. „Doroczna kampania polityczno-kulturalna winna w obliczu nowych zadań stać się dźwignią rozszerzenia i umocnienia narodowego frontu walki o pokój i plan 6-letni”. Dni powinny „pogłębić w narodzie uczucia patriotyzmu i internacjonalizmu, uczucie braterstwa $z$ ZSRR i nienawiści dla amerykańskohitlerowskich agresorów imperialistycznych. [...] Polityczno-propagandowa praca $w$ toku akcji winna budzić uczucia dumy narodowej $z$ osiąnięć naszej teraźniejszości, ze wspaniałych perspektyw naszej przyszłości i z pięknych tradycji postępowych naszej historii, winna budzić świadomość, że Polska Ludowa opiera się na całym dziejowym dorobku naszej kultury i nauki, a budownictwo

\footnotetext{
${ }^{21}$ Zespoły czytelnicze. Instrukcja dla kół gromadzkich ZSCh, Warszawa 1951, s.3-14.

${ }^{22}$ AAN, ZG ZSCh, 1491, Uchwała Prezydium Zarządu Głównego z dnia 30 września 1953 roku [projekt], k. nlb.
} 
socjalizmu pomnaża go wielokrotnie, napełnia go nową treścią i udostępnia najszerszym masom. Dni O[światy] K[siążki] [i] P[rasy] powinny przyczynić się do podniesienia świadomości politycznej i wzbogacenia życia kulturalnego narodu przez pogłębienie czytelnictwa prasy, spopularyzowanie naszego dorobku kulturalnego wśród najszerszych mas”. Okazją do uroczystych obchodów „w przodujących gromadach, gminach, powiatach i województwach” miała być „całkowita likwidacja analfabetyzmu”. Wśród wielu form kampanii związanej z Dniami znalazły się również takie, które były adresowane szczególnie do społeczności wiejskich. Należały do nich wyjazdy ekip szkół zawodowych na wieś w celu propagandy szkolnictwa zawodowego czy pomocy w remoncie maszyn rolniczych w ramach ruchu łączności miasta ze wsią. Postulowano zorganizowanie punktów sprzedaży książek w spółdzielniach gminnych, tworzenie odpowiednich stoisk na jarmarkach i targach, „uruchamianie bibliobusów oraz księgonoszy przez stałe i specjalnie powstające ekipy łączności i grupy kolporterów na wieś zwłaszcza do P[aństwowych] O[środków] M[aszynowych], P[aństwowych] G[ospodarstw] R[olnych] i spółdzielni produkcyjnych”. Mieszkańcy wsi mieli być respondentami ankiety zatytułowanej: „Jakie książki przeczytałem w zimie i co o nich myślę"23.

Główny kierunek tej imprezy w maju 1954 r. miał być - jak pisano w odpowiedniej instrukcji - „nacelowany na wieś”. Dni winny przyczynić się do mobilizacji - „Za przykładem ZSRR” - nauki, wiedzy, techniki i sztuki na rzecz szybszego podniesienia poziomu rolnictwa i jego rozwoju w kierunku socjalistycznym. Zalecano, aby w trakcie ich trwania nadać większy rozmach współzawodnictwu o prawo uczestniczenia w wystawie rolniczej, szerzej rozwinąć propagandę ,przodującego doświadczenia i wiedzy rolniczej”. Trzeba - czytamy w tym dokumencie - umasowić czytelnictwo książek i czasopism rolniczych, „wprząc” do tego Towarzystwo Wiedzy Powszechnej, służbę rolną i szkoły ${ }^{24}$.

Cytowane teksty publicystyczne i fragmenty oficjalnych dokumentów należą do „świata przedstawien” stalinowskiej władzy. Na ile odzwierciedlały one rzeczywiste problemy związane $z$ czytelnictwem i funkcjonowaniem książki na wsi polskiej w analizowanym okresie? Jaki był stosunek jej mieszkańców do nich? Odpowiedzi na tak postawione pytanie należy poszukiwać w dokumentacji archiwalnej wówczas wytworzonej, istniejącej, choć niezbyt bogatej literaturze przedmiotu oraz w materiałach autobiograficznych.

${ }^{23}$ AAN, KC PZPR, 1636 (mikr. 2819), Główny Komitet Obywatelski Dni Oświaty, Książki i Prasy, Instrukcja w sprawie organizacji Dni Oświaty, Książki i Prasy, Warszawa, 16 kwietnia 1951.

${ }^{24}$ AAN, KC PZPR, 1662 (mikr. 2825), Instrukcja Sekretariatu KC PZPR w sprawie organizacji Dni Oświaty, Książki i Prasy 1954 r., k. 159. 


\section{Książka i czytelnictwo na wsi: realia}

Zanim zostanie dokonana próba przedstawienia ustaleń, dotyczących chłopskiego czytelnictwa ksiazżek, nieodzowna wydaje się analiza działań władz (i reakcji na nie) związanych ze wzmiankowaną wcześniej kampanią zwalczania analfabetyzmu. Posiadanie umiejętności czytania (i pisania) było wszak niezbędną kompetencją umożliwiającą korzystanie $z$ książek i to bez względu na to, czy sposób, w jaki to czyniono był zgodny z celami politycznych decydentów.

Dla realizacji zadań postawionych w tej kampanii, a skodyfikowanych we wzmiankowanej już ustawie z 7 kwietnia $1949 \mathrm{r}^{25}$ powołany został Pełnomocnik Rządu do Walki $z$ Analfabetyzmem, pełnomocnicy wojewódzcy i powiatowi oraz sieć komisji społecznych działających przy pełnomocnikach, a na szczeblu gmin - przy ich zarządach.

Oficjalnie publikowane dokumenty nie zawierają informacji, jak liczna była rzesza analfabetów i półanalfabetów przeszkolonych na wsi. Zarząd Główny ZSCh powołując się na opracowanie Głównej Komisji do Walki z Analfabetyzmem twierdzil, że na blisko 760 tys. osób, które przystąpiły do egzaminów kończących naukę pisania i czytania i otrzymały świadectwa ponad 567 tys. przypadało na wieś. Ustalenia te są tym ważniejsze, że Związek od 1950 r. objął opiekę nad wszystkimi kursami nauki początkowej na wsi, bez względu na to, jaka organizacja je prowadziła. Zorganizował ich w latach 1949 - 1951 ponad 20,5 tys., wzięło udział ponad 311 tys. słuchaczy. W samym ZSCh było ponad 158 tys. analfabetów, $z$ których ponad 25 tys. zwolniono $z$ nauki $z$ powodu podeszłego wieku, a blisko 120 tys. otrzymało świadectwa ukończenia kursu ${ }^{26}$. Tadeusz Pasierbiński na podstawie zestawień statystycznych opracowanych przez Pełnomocnika Rządu podaje, że liczba absolwentów nauczania początkowego wynosiła na wsi (1 grudnia 1951) 486361, a w mieście $131937^{27}$.

Ukończenie kursu początkowego nauczania $\mathrm{w}$ intencjach władz miało stanowić jedynie pierwszy etap kampanii na rzecz likwidacji analfabetyzmu. Następne kroki w tej dziedzinie podejmowano zgodnie $z$ ustawą $z 15$ lutego $1952 \mathrm{r}$. o zmianie form organizacji nauczania początkowego dorosłych (Dz.U. nr 11, poz. 66). Utrwaleniu zdobytych umiejętności miały służyć konkursy czytelnicze, wieczory głośnego czytania, wieczory dyskusyjne, żywego słowa, koła korespondentów terenowych itp. Biuro Pełnomocnika Rządu do Walki z Analfabetyzmem opracowało instrukcję o organizowaniu zespołów czytelniczych ${ }^{28}$.

Zasięg tych zespołów był znacznie mniejszy niż kursów dla analfabetów. Ich liczba (w mieście i na wsi) wynosiła: w 1951 r. - 4800, 1952 - 7100, 1953 - 4349, $1954-5330,1955-4932,1956-4859$. Nie rozwiązały one w pełni problemu analfabetyzmu w Polsce. Zaczął się on ujawniać wśród młodych roczników. Nie-

${ }^{25}$ Ustawa z dnia 7 IV 1949 r. o likwidacji analfabetyzmu, Dz.U. nr 25, poz. 177.

${ }^{26} \mathrm{AAN}, \mathrm{ZG}$ ZSCh, 1472, Organizacja zespołów czytelniczych jako drugi etap walki $z$ analfabetyzmem [1951], s. 147.

${ }^{27}$ T. Pasierbiński, Problemy likwidacji analfabetyzmu w Polsce Ludowej, Warszawa 1960, s. 125-128.

${ }^{28}$ AAN, ZG ZSCh, 1472, Nauczanie początkowe dorosłych, s. 113. 
przypadkowo przecież w latach 1952-1955 na kursach dla analfabetów przeszkolono w wojsku prawie 34000 poborowych. Tylko niewielki procent byłych analfabetów - absolwentów kursów uczył się nadal w szkołach dla dorosłych ${ }^{29}$.

O tym, że informacje, dotyczące rozwoju czytelnictwa należy traktować $z$ dużą ostrożnością świadczą odnalezione informacje na temat przebiegu niektórych $z$ tych kursów na wsi. Nie wszyscy chłopi, którzy podlegali nauczaniu (zgodnie $z$ ustawą - osoby między 14 a 50 rokiem życia) faktycznie chcieli podjąć ten wysiłek. Wobec niektórych $z$ nich podjęto środki represyjne w postaci m.in. doprowadzania do miejsca nauki przy użyciu milicjantów. Potwierdzenie stosowania tego typu praktyk odnajdujemy w sprawozdawczości Pełnomocnika Rządu ${ }^{30}$ i ZSCh. Zarząd Powiatowy Związku w Drawsku na początku 1951 r. dla podniesienia frekwencji na kursach w czterech gminach postanowił, aby „upornych wzywać przez GRN i organa MO celem przemówień, aby raz na zawsze skończyć i zlikwidować analfabetów”31. Po zastosowaniu takich środków frekwencja znacznie się podniosła. W powiecie nyskim na Opolszczyźnie: „opornych, na których nie wpływają pouczenia o konieczności uczęszczania na kurs, wzywano do Gminnych Rad Narodowych, gdzie przeprowadzano nauczanie. Szczególnie opornych wzywa się do Prezydium Powiatowej Rady Narodowej, gdzie naucza się ich na miejscu"32.

W sprawozdawczości ZG ZSCh można również odnaleźć informację o tym, że w gromadzie Firlej zarejestrowano trzynastu analfabetów, którzy nie chcieli uczęszczać na kursy. Aby złamać chłopski opór milicjanci zamknęli ich w areszcie ucząc przez jeden dzień. Dla podniesienia frekwencji sporządzano listy osób podlegających nauczaniu początkowemu, które miały być przekazane sprzedawcom sklepowym wraz $z$ poleceniem, aby nieuczęszczającym na kursy nie sprzedawać żadnych towarów ${ }^{33}$.

O tym, że statystyka obrazująca liczbę kursów i osób, które faktycznie nauczyły się czytać i pisać bywała zawyżana świadczą chociażby wspomnienia wiejskiej nauczycielki $z$ województwa lubelskiego. Jej koleżanka tak przedstawiła swój „sposób” na analfabetów: „Ja się nie szarpałam z nimi. Od razu zwołałam kilkunastu znajomych chłopów. Powiadomiłam przedstawicieli z Gminnego Komitetu do Walki z Analfabetyzmem. Uzgodniliśmy, kto za jakiego analfabetę ma zdawać (...). Potem bimbka, bo egzamin wypadł nadzwyczaj pomyślnie” ${ }^{34}$. Nierzadkie były przypadki, że pięciomiesięczne kursy nauczania pisania

${ }^{29}$ J. Półturzycki, Rozwój i problemy szkolnictwa dla dorosłych w Polsce Ludowej, Ossolineum 1972, s. 3637; J. Landy-Tołwińska, Analfabetyzm w Polsce. Analfabetyzm w Polsce i na świecie, Warszawa 1961, s. 110.

${ }^{30}$ T. Pasierbiński, dz.cyt., s. 93.

${ }^{31}$ AAN, ZG ZSCh, 1476, ZP ZSCh w Drawsku do ZG ZSCh, 10 II 1951.

${ }^{32}$ AAN, ZG ZSCh, 1478, Sprawozdanie $z$ walki $z$ analfabetyzmem Zarządu Powiatowego ZSCh w Nysie za miesiąc styczeń 1951 r., k. nlb.

${ }^{33}$ AAN, ZG ZSCh, 1477, Sprawozdanie opisowe $z$ przebiegu zwalczania analfabetyzmu w powiecie Lubartów.

${ }^{34}$ Byłe Centrum Pamiętnikarstwa Polskiego w Rudnie (dalej: CPP), Młode Pokolenie Wsi Polski Ludowej (dalej: MPWPL), Pamiętnik nr 3913. CPP od wielu lat nie istnieje. Jego zbiory prawdopodobnie przejęło Archiwum Akt Nowych. 
i czytania były skracane do 2-3 miesięcy. Mimo podjętych wysiłków brakowało wystarczającej ilości literatury przeznaczonej dla uczących się analfabetów ${ }^{35}$. Jako objaw „walki klasowej” w trakcie tej akcji wskazywano na pojawiające się w niektórych powiatach województwa zielonogórskiego pogłoski o wampirze, który miał napadać na kobiety wracające $z$ kursu ${ }^{36}$.

Na liczne uchybienia w tej akcji wskazano na posiedzeniu Prezydium Głównej Komisji Społecznej do Walki z Analfabetyzmem w dniu 26 czerwca $1951 \mathrm{r}$. Stwierdzono, że poziom na kursach nie zawsze był dostatecznie wysoki. Sztucznie przyspieszano egzaminy, „nawet bez dokończenia «Startu» [elementarz dla analfabetów - D.J.]”. Ich poziom bywał zaniżany. Na wielu zajęciach regułą była niska frekwencja. Krytykowano zbytni liberalizm w zwalnianiu $z$ obowiązku nauczania, zwłaszcza w województwach: rzeszowskim, warszawskim, poznańskim i lubelskim ${ }^{37}$.

Opinie te potwierdzają niektóre sprawozdania terenowe. Trudną do pokonania przeszkodą był brak okularów, zwłaszcza dla starszych uczestników kursów, oraz - we wsiach niezelektryfikowanych - szkieł i lamp naftowych. Rejestracja analfabetów była często przeprowadzana niedokładnie „po linii najlżejszego oporu" i pomijała, bez żadnego uzasadnienia, wiele osób zobowiązanych do nauczania zgodnie $z$ literą prawa ${ }^{38}$. W Zielonogórskiem stwierdzono, iż Wojewódzki Wydział Oświaty był zasypywany przed podinspektorów do spraw walki $z$ analfabetyzmem fikcyjnymi, zbyt „optymistycznymi” sprawozdaniami. W Katowickiem w wyniku zbytniej gorliwości rejestrowano jako analfabetów nieumiejących czytać i pisać po polsku, ale czytających i piszących po niemiecku. Zdarzało się, że w niektórych powiatach tego województwa autochtoni byli traktowani jako półanalfabeci, a kursy nauczania języka polskiego nie wyodrębniono z ogólnej liczby kursów nauczania początkowego. Niezbędnej w przypad-

\footnotetext{
${ }^{35}$ J. Półturzycki, dz. cyt., s. 37-38.

${ }^{36}$ AAN, BPRdWA, 93, Przebieg i wyniki walki $z$ analfabetyzmem w województwie zielonogórskim [maj 1951], s. 179-182.

${ }^{37}$ AAN, BPRdWA, 16, Protokół nr 24 z posiedzenia Prezydium Głównej Komisji Społecznej do Walki z Analfabetyzmem w dniu 9 IV 1951, k. 88; ibidem, Protokół nr 28 z posiedzenia Prezydium Głównej Komisji Społecznej do Walki z Analfabetyzmem w dniu 26 VI 1951, k. 100-103.

${ }^{38}$ AAN, BPRdWA, 57, Sprawozdanie $z$ wizytacji województwa pomorskiego w zakresie stanu likwidacji analfabetyzmu dokonanej przez delegata Pełnomocnika Rządu do Walki z Analfabetyzmem i min. wiz. szk. Żytkę Mieczysława w dniach 20-24 kwietnia 1950 r., k. 33-34. Symptomatyczna pod tym względem wydaje się uwaga poczyniona przez inspektora szkolnego na wojewódzkiej naradzie pełnomocników do spraw walki $z$ analfabetyzmem, jak się odbyła 10 września 1950 r., który stwierdził: „Brak należytego zrozumienia przez organizacje społeczne i samorząd, a nawet władze szkolne dla tak fundamentalnej akcji jak rejestracja doprowadził do tego, że jeszcze dziś nie wiemy ilu analfabetów posiadamy w województwie i ilu mamy nauczać. Nie przeprowadzono dodatkowej rejestracji zarządzonej przez Pełnomocnika Rządu w Tygodniu Oświaty b.r. [...]. Niedbale przeprowadzona rejestracja w wielu innych powiatach, np. w pow. rypińskim w gromadzie Samosiery sołtys zwrócił arkusz rejestracyjny czysty z oświadczeniem, że w jego gromadzie analfabetów nie ma, gdy kontrola podinspektora wykryła 22 analfabetów ogółem a 12 do nauczania. W gromadzie [Jeszcz] powiatu świeckiego mimo dwukrotnej rejestracji 1949 r. nie wykryto analfabetów, a kierownik szkoły sam wykrył 12 osób do nauczania”. Zob. BPRdWA, 57, k. 59.
} 
ku takiej akcji pieczołowitości nie sprzyjał pośpiech, wzmacniany zastosowaniem reguł współzawodnictwa ${ }^{39}$.

O budzącej wątpliwości skuteczności akcji, zwłaszcza na wsi, zdają się świadczyć informacje, zawarte w wielu sprawozdaniach szczegółowych, o frekwencji na kursach. Oto np. wizytator odwiedzający województwo katowickie w listopadzie 1950 r. stwierdzał, że wahała się ona od 20 do 90\%. Ponadto zauważał: „Na dwóch zespołach w Dobrodzieniu nie było nauki, ponieważ słuchacze biorą udział w misjach. W gminach i gromadach, w których frekwencja jest słaba, a opory psychiczne $z$ powodu fałszywego wstydu duze, jest tendencja do rozbudowywania form nauczania indywidualnego". Efektów tego ostatniego nie udało się ocenićc ${ }^{40}$.

We Wrocławskiem w styczniu 1951 r. uruchomiono 51\% zaplanowanych kursów, na których frekwencja dochodziła do $48 \%$ zapisanych. Byli to przede wszystkim analfabeci „którzy w większości wypadków pod naciskiem społecznym, a nie dobrowolnie zgłosili się na kursy”. Wizytatorka tej akcji stwierdzała, ze wśród zapisanych „znajduje się spora liczba złośliwie opornych i wielu tumanionych przez wroga klasowego" - i to oni byli rzekomo główną przyczyną absencji na zajęciach ${ }^{41}$.

Na wsi konkurencją dla kursów stawały się pilne prace polowe. Zdarzało się również, że dorośli analfabeci - uczestnicy nauczania stawali się przedmiotem kpin i żartów ${ }^{42}$. W pogoni za uzyskaniem imponujących wskaźników ilościowych rejestrowano niekiedy na kursy nauki początkowej osoby, które ukończyły nawet sześć klas szkoły podstawowej. Szwankowała praca organizacji społecznych zajmujących się ta akcją, co najczęściej oznaczało, że cały ciężar jej realizacji był przerzucany na nauczycieli i administrację szkolną ${ }^{43}$.

${ }^{39}$ AAN, BPRdWA, 16, Protokół nr 15 z posiedzenia Prezydium Głównej Komisji Społecznej do Walki z Analfabetyzmem w dniu 22 I 1951, k. 49; ibidem, Protokół nr 17 z posiedzenia Prezydium Głównej Komisji Społecznej do Walki z Analfabetyzmem w dniu 5 II 1951, k. 55; AAN, BPRdWA, 55, Sprawozdanie $z$ wizytacji woj. białostockiego w zakresie stanu likwidacji analfabetyzmu dokonanej przez delegata Pełnomocnika Rządu Serafina Garbińskiego w dn. 23-31 III 1950, Warszawa 3 IV 1950, k. 4-8; AAN, BPRdSWA, 169, Sprawozdanie $z$ dotychczasowego przebiegu akcji likwidacji analfabetyzmu [kwiecień 1950]; AAN, BPRdSWA, 61, Sprawozdanie $z$ wizytacji woj. katowickiego w zakresie walki $z$ analfabetyzmem, dokonanej w dniach od 21 do 24 listopada 1950 r. przez delegata Pełnomocnika Rządu do Walki z Analfabetyzmem - min. wiz. ob. Serafina Garbińskiego, k. 112.

${ }^{40}$ AAN, BPRdWA, 61, Sprawozdanie $z$ wizytacji woj. katowickiego..., dz. cyt., k. 111.

${ }^{41}$ AAN, BPRdWA 92, Sprawozdanie $z$ wizytacji województwa wrocławskiego ze stanu walki $z$ analfabetyzmem, przeprowadzonej przez delegata Pełnomocnika Rządu do Walki z Analfabetyzmem pos. Stanisławę Garncarczykową w dniach od 13 do 25 stycznia 1951 r., k. 6.

${ }^{42}$ AAN, BPRdWA, 57, Sprawozdanie $Z$ wizytacji prac wojewódzkiej Komisji społecznej do Walki z Analfabetyzmem i Wydziału Oświaty Kuratorium Okręgu Szkolnego w Toruniu dokonanej w dn. 5 października 1949 r. przez min. wiz. szkół ob. Garbińskiego Serafina, k. 5.

${ }^{43}$ AAN, BPRdWA, 57, Sprawozdanie $z$ wizytacji województwa pomorskiego w zakresie stanu likwidacji analfabetyzmu przez delegata Pełnomocnika Rządu do Walki z Analfabetyzmem i min. wiz. szk. Żytkę Mieczysława w dniach 1 do 6 lutego oraz 1 do 7 marca 1950 r., ibidem; Sprawozdanie z zapoznania się $z$ przygotowaniem i z przebiegu plenarnego zebrania wojewódzkiej Komisji Społecznej do W.A. w wojewódzkie bydgoskim, Warszawa 17 sierpnia 1950, k. 40. 
W świetle przytoczonych faktów uzasadniony wydaje się wniosek, że realizowana przy wielkim nakładzie środków finansowych i zaangażowaniu nie tylko nauczycieli akcja nie była na pewno tak skuteczna jak głosiły to władze państwowe. Zabrakło konsekwencji w jej kontynuowaniu, opieki nad tymi, którzy ukończyli kursy. Nawet jeżeli optymistycznie założymy, iż do stycznia 1952 r. nauczyło się czytać i pisać nieco ponad $1 \mathrm{mln}$ ich absolwentów (łącznie $z$ tymi, które były organizowane przed 1949 r.), to i tak jest to tylko część zbiorowości pozbawionych tej umiejętności, szacowanej w pierwszych latach po wojnie na 33,5 mln osób. Warto przypomnieć, iż spisy powszechne z 1950 i 1960 r. wykazały, że wskaźnik procentowy liczby analfabetów w Polsce co prawda zmniejszył się, ale nie tak radykalnie, jak skłonni bylibyśmy przypuszczać: z 5,8\% do 4,6\% ludności krajü4.

Ponadto trudno oszacować, jaka liczba absolwentów omawianych wcześniej kursów opanowała w sposób zadowalający wówczas zdobywane umiejętności. Do ostrożności w formułowaniu zbyt optymistycznych sądów na ten temat skłaniają badania 973 z nich przeprowadzone w 1963 r. Okazało się, iż tylko 40\% czytało powoli, dostatecznie lub dobrze, a $60 \%$ - z trudem lub nie czytało w ogóle (dla badanych rolników indywidualnych odpowiednie wskaźniki wyniosły $42,1 \%$ i $57,9 \%)^{45}$.

Jak w świetle przeprowadzonych kwerend jawi się ówczesne wiejskie czytelnictwo?

Zachowane archiwalia świadczą, że jego rozwój nie postępował szybko, a stosowane metody przyspieszenia tego procesu były dalekie od dobrowolności. Miały one zmusić mieszkańców wsi do kupowania książek i prasy. I tak w gminie Gidle w województwie łódzkim na początku 1951 r. stwierdzono, że „przy wypłacaniu renty lub wydawaniu paczek zagranicznych wmusza się w chłopów książkę lub prenumeratę czasopism. W gminie Wielgomłyny listonosze dają chłopom gazety «na kredyt». We wsi Chełmno (gmina Masłowice) listonosz zostawia w miejscowym sklepie GS trzydzieści kilka egzemplarzy «Gromady» celem rozsprzedaży. Sklepowa często wydaje resztę "Gromadą»"46. Takie procedery stosowane były przez wiejskich listonoszy w całym kraju ${ }^{47}$, choć określenie skali ich nasilenia wydaje się na tym etapie badań niemożliwe.

O tym, ze opisany przypadek „popularyzacji” czytelnictwa przy wykorzystaniu sklepów GS nie był odosobniony świadczy odnaleziona w materiałach źródłowych informacja o tym, jak w Tyńcu w województwie krakowskim w 1954 r. chłopów zmuszano do zakupu książek pod groźbą nie sprzedania im innych, szczególnie pożądanych towarów (węgiel, nawozy sztuczne, drzewo budulco-

\footnotetext{
${ }^{44}$ J. Półturzycki, dz.cyt., s. 38.

${ }^{45}$ Zob.: Absolwenci kursów nauczania początkowego. Badania ich rozwoju kulturalnego po kilkunastu latach, praca pod kierunkiem J. Landy-Tołwińskiej, Warszawa 1970, s. 15-35, 187.

${ }^{46}$ AAN, KC PZPR, 237/XIX-50, Stan czytelnictwa na terenie gmin wiejskich Łodzi, Łódź, 13 II 1951.

${ }^{47}$ J. Giera, Polityczne aspekty działalności pocztowców na wsi na przełomie lat 40-tych i 50-tych, w: Wieś - chłopi - ruch ludowy - państwo. Księga pamiątkowa Profesora Józefa Ryszarda Szaflika, Warszawa 1996, s. 195-196.
} 
we): „Narzucają książki według ilości zakupionego towaru - skarżył się jeden $z$ rolników - gdy kupuje się większą ilość towaru to dają książki droższe. Nad biurkiem sprzedającej wisi dyplom uznania za rozpowszechnianie czytelnictwa na wsi”. Taką samą praktykę stosowały gminne spółdzielnie (GS) w Zaklikowie i Urzędowie w powiecie Kraśnik w województwie lubelskim ${ }^{48}$. O tym, że zasięg tego rodzaju praktyk był znacznie szerszy, świadczy odnalezione i zanalizowane przez Stanisława Kondka „Sprawozdanie syntetyczne $z$ pobytu ekip delegowanych do 8 powiatów województwa kieleckiego, poznańskiego, warszawskiego i wrocławskiego dla zbadania stanu czytelnictwa” z lutego 1953 r. Okazało się, że w powiecie dzierżoniowskim „ceną za załatwienie jakiejśs urzędowej sprawy u sołtysów było wykupienie broszur o tematyce rolniczej”, a w sklepach powiatu pułtuskiego sprzedaż wódki była powiązana $z$ koniecznością kupna książki ${ }^{49}$.

$Z$ drugiej strony w analizowanych materiałach można znaleźć informacje świadczące o lekceważeniu propagandy czytelnictwa. Kontrola pracy kulturalno-oświatowej w województwie kieleckim w 1954 r., przeprowadzona przez funkcjonariuszy Wydziału Propagandy KC PZPR wykazała, że w wielu GS-ach zakurzone książki trzymane były pod ladą i w ogóle ich nie sprzedawano ${ }^{50}$. Efekty różnych metod rozpowszechniania książek i prasy nie zawsze były zgodne $z$ założeniami jej inicjatorów. Nauczyciel ze wsi Żdżary koło Rawy Mazowieckiej, który sam ofiarnie włączył się w tę akcję wspominał: „Jakież było moje rozczarowanie, gdy na ogłoszoną wśród dzieci zbiórkę makulatury w komórce szkolnej znalazła się znaczna część książek, i to bardzo często o nierozciętych kartkach, które ja sam rozprowadzałem"

Wiele sprawozdań „Z terenu” przesyłanych do wyższych instancji partyjnych zawierało informacje o złym stanie wiejskich bibliotek. Skłoniło to Wydział Kultury KC PZPR do zorganizowania w maju 1953 r. kontroli ich pracy i czytelnictwa na wsi. Bezpośrednimi wykonawcami tej akcji w poszczególnych województwach byli członkowie specjalnie powołanych komisji Komitetów Wojewódzkich partii. Skontrolowano wybrane gromady w 2-3 powiatach w każdym województwie. W zachowanym zbiorczym materiale sprawozdawczy $z$ tych inspekcji pisano, że większość bibliotek gminnych nie posiadało izb na czytelnie. Wiele punktów bibliotecznych nie przejawiało prawie żadnej działalności. Komplety książek, w które były zaopatrywane wymieniano zwykle dopiero po pół roku. Okazało się, że kilkanaście tysięcy gromad nie posiadało takich punktów. Stwierdzono równiė̇, że zjawiskiem częstym było składowanie książek na strychach lub pod łóżkami w mieszkaniach prywatnych. Szacowano, że czytel-

${ }^{48}$ Archiwum Zakładu Historii Ruchu Ludowego (dalej: AZHRL), Naczelny Komitet Zjednoczonego Stronnictwa Ludowego (dalej: NK ZSL), 409, Listy ze wsi w okresie akcji siewnej, Biuletyn 5-W, 17 IV 1954, s. 64.

${ }^{49}$ Cytaty za: S. A. Kondek, Papierowa rewolucja. Oficjalny obieg ksiąiek $w$ Polsce $w$ latach $1948-$ 1955, Warszawa 1999, s. 65.

${ }^{50}$ AAN, KC PZPR, 237/VIII-434, Sprawozdanie z pracy Wydziału Propagandy KC PZPR w województwie kieleckim 6-25 X[1954], k. 16.

${ }^{51}$ AZHRL, Pamiętniki nauczycieli (Ankieta z 1958 r.), P-194, Pamiętnik Stanisława Górala. 
nicy wiejscy stanowili około 10\% ogółu ludności wsi. Jako zły oceniono stan czytelnictwa w spółdzielniach produkcyjnych. Zjawiskiem nagannym było również słabe czytelnictwo aktywu partyjnego ${ }^{52}$. Podobne konkluzje kończyły sprawozdanie $z$ działalności kulturalno-oświatowej ZSCh w 1954 r. Jego autorzy utrzymywali, że „Biblioteki gromadzkie są źle prowadzone, nie ma inwentarza, katalogów, brakuje druków bibliotecznych, szaf. Jeszcze gorzej prowadzi się punkty biblioteczne, które najczęściej mieszczą się w szkole lub prywatnym mieszkaniu nauczyciela, dokąd ludność rzadko chodzi”s3. Przeprowadzona w czerwcu 1953 r. analiza czytelnictwa w województwie kieleckim wykazała, że na blisko 230 bibliotek gminnych około 100 nie posiadało własnego lokalu. Odnotowano dużą płynność kadr bibliotekarzy głównie ze względu na trudności mieszkaniowe i niskie płace ${ }^{54}$.

Te pesymistyczne wnioski potwierdzają sprawozdania $z$ wizytacji punktów bibliotecznych w spółdzielniach produkcyjnych i PGR-ach wielu województw przeprowadzonych w 1952 r., zachowane w aktach Centralnego Zarządu Bibliotek. Jako typową można potraktować analizę dotyczącą województwa bydgoskiego. Ustalono, iż większość punktów bibliotecznych znajdowała się w złych warunkach lokalowych (33 w lokalach prywatnych, $30 \mathrm{w}$ lokalach zbiorowych, $117 \mathrm{w}$ świetlicach, ,ale najczęściej nieopalonych, brudnych, niesprzątanych, co w żadnym wypadku nie daje sprzyjających warunków dla rozwoju czytelnictwa”). W 48 bibliotekach brakowało „wszelkiego rodzaju sprzętu”. Książki niszczyły się i były narażone na zagubienie. W innych przypadkach, „gdzie jest nieodzowny sprzęt spotyka się szafy otwarte, co niewątpliwie świadczy o daleko idącym niedbalstwie". Narzekano na personel biblioteczny (kierownicy punktów, często zmieniający się, nieprzygotowani do prowadzenia najprostszych prac jak ewidencja czytelników, statystyka itp.). Podobne uwagi można odnaleźć w sprawozdaniach dotyczących innych województw ${ }^{55}$.

Biblioteki wiejskie, mimo wskazanych trudności w realizacji swych podstawowych zadań, zgodnie $z$ obowiązującym modelem działania, uczestniczyły w propagowaniu celów ideologiczno-politycznych państwa. Zachowane sprawozdania $z$ działalności bibliotek wiejskich $z$ lat: 1952 i 1954 potwierdzają zaangażowanie ich personelu (nierzadko jednoosobowego) w agitację wyborczą (w charakterze kolporterów broszur i agitatorów). Bibliotekarze urządzali okolicznościowe wystawy (zwłaszcza w maju z okazji Dni Oświaty Książki i Prasy), akademie, gazetki ścienne, pogadanki. Jaka była skuteczność tych działań trudno ustalić. Wiadomo, że musieli się oni borykać z sezonowością ruchu czy-

${ }^{52}$ AAN, KC PZPR, 237/VII-139, Zestawienie meldunków z terenu nr 13/59 za okres do 15 VIII 1953, k. 391-392.

${ }^{53}$ AAN, ZG ZSCh, 1638, Sprawozdanie z działalności kulturalno-oświatowej ZSCh [1954], dz.cyt, k. 74.

${ }^{54}$ AAN, KC PZPR, 237/XVIII-13, Ocena analizy pracy bibliotek województwa kieleckiego, $16 \mathrm{VI}$ 1953, s. $90-105$.

${ }^{55}$ AAN, Ministerstwo Kultury i Sztuki - Centralny Zarząd Bibliotek (dalej: MKiS, CZB), 93, Część opisowa do sprawozdania liczbowego $z$ wizytacji punktów bibliotecznych w spółdzielniach produkcyjnych i PGR-ach w wojew. Bydgoskim [1952], k. 1. Tamże sprawozdania $z$ innych województw. 
telniczego (małe zainteresowanie książką w okresie pilnych prac polowych) oraz brakiem wyposażenia i opału dla budynków bibliotek ${ }^{56}$.

Jakie były gusta czytelnicze ówczesnych mieszkańców wsi i ich zainteresowanie biblioteką jako instytucją społeczną? Odpowiedź na to pytanie jest trudna ze względu na niedostatek odpowiednich analiz. Badania Instytutu Ksiązki i Czytelnictwa wykazały, że w skali ogólnopolskiej w 1956 r. z bibliotek wiejskich korzystało około $12 \%$ ludności wiejskiej. Wskaźnik literatury pięknej w księgozbiorach gromadzkich zbliżał się średnio do 60\%, literatury dziecięcej - wynosił około 10\%. Szczegółowe ustalenia pracowników tej placówki, oparte przede wszystkim o monograficzne opisy sześciu wybranych wsi i ankiety, rozesłane do kilkuset bibliotek gromadzkich wykazały przede wszystkim małe zainteresowanie literaturą rolniczą. W tej grupie wydawnictw najczęściej były czytywane popularne poradniki $z$ dziedziny gospodarstwa domowego, sadownictwa i dotyczące specjalnych upraw czy hodowli aktualnie propagowanych (nutria, kukurydza) oraz szersze opracowania „na wyższym poziomie”, jak na przykład „Poradnik weterynarza”. Wynikało to m.in. $z$ faktu, że w bibliotekach znajdowało się mnóstwo wieloegzemplarzowych broszur kierowanych tam w ramach różnych akcji, masowo kolportowanych na wsi i nabywanych na własność, a więc nie poszukiwanych w bibliotekach. Brakowało literatury rolniczej związanej ze specyfiką terenu, właściwościami gleby, tradycjami hodowlanymi oraz wydawnictw poradnikowych i naukowych, ale napisanych w sposób przystępny, „w sposób budzący zaufanie do rzetelności podanej wiedzy”. Wśród wydawnictw popularnonaukowych dużym stosunkowo zainteresowaniem cieszyły się książki na temat higieny - czytały je głównie kobiety i inteligencja wiejska. Polska wieś wyraźnie odrzucała literaturę społeczno-polityczną; wypożyczenia $\mathrm{w}$ tym dziale stanowiły $\mathrm{w}$ badanych bibliotekach gromadzkich 3,4\% ich ogółu podczas gdy w ich księgozbiorze takich pozycji było około 15\%. Najczęstszymi ich czytelnikami była młodzież, najpewniej - jak słusznie przypuszczano - w związku ze szkoleniami ZMP-owskimi i miejscowa inteligencja $-z$ tych samych powodów.

Wśród dzieł literatury pięknej szczególną popularnością cieszyły się utwory „starych” polskich klasyków (Henryk Sienkiewicz, Stefan Żeromski, Bolesław Prus, Józef Ignacy Kraszewski, Eliza Orzeszkowa) oraz niektórych autorów współczesnych (Karol Bunsch, Janusz Meissner, Igor Newerly, Zofia Nałkowska, Maria Dąbrowska) ${ }^{57}$. Podobne wyniki dała analiza preferencji czytelniczych

${ }^{56}$ AAN, MKiS, CZB, 193, Sprawozdania z działalności bibliotek gminnych w 1952 r. (różne województwa), k. nlb.; AAN, MKiS, CZB 105, T. Stanisz, Opis bibliotek i czytelnictwa w gminie Kosina pow. Łańcut [1954].

${ }^{57}$ AAN, MKiS, CZB, 172, Stenogram Sekcji Czytelnictwa Wiejskiego Ogólnopolskiego Zjazdu Bibliotekarzy, 16 II 1956, k. 1-39. Krystyna Remerowa, referująca wyniki tych badań, miała wątpliwości dotyczące skali czytelnictwa wiejskiego: „Budzą się równiė̇ wątpliwości np. czy można między liczbą wypożyczeń i liczba książek przeczytanych stawiać znak równości, skoro od niedawna a bodajże i dziś niektóre biblioteki do poczytnych książek dodają «martwe» pozycje, trochę w intencji - a może «chwyci», a trochę... dla celów statystycznych. Albo - ile pozycji wśród książek wypożyczanych przez 
dorosłych, przeprowadzona w 1956 r. w kilkudziesięciu wsiach łowickich przez Józefa Kuczyńskiego. Wśród autorów najbardziej popularnych znaleźli się tam Józef Ignacy Kraszewski, Bolesław Prus, Maria Rodziewiczówna, Eliza Orzeszkowa, Władysław Reymont i Lucjan Rudnicki ${ }^{58}$. O tym, że takie gusta dominowały również wcześniej, świadczą cytowane sprawozdania $z$ kontroli punktów bibliotecznych w spółdzielniach produkcyjnych i PGR z 1952 r. oraz szczegółowe opisy czytelnictwa, dotyczące wybranych gmin z $1954 \mathrm{r}^{59}$.

W wielu szczegółowych sprawozdaniach podkreślano, że wiejscy czytelnicy poszukiwali przede wszystkim beletrystyki „o żywej, barwnej akcji”, książek podróżniczych „Z przygodami, koniecznie $z$ wątkiem miłosnym” ${ }^{\circ 0}$. Niektórzy nauczyciele wiejscy wspominali, że spotykali się często $z$ żądaniami książek „takich jak dawniej”, chodź autorzy tych wypowiedzi często nie umieli dokładniej sprecyzować swych gustów. Owe żądania „dawnych” książek były formułowane na zasadzie opozycji literatury współczesnej, ocenianej jako nieciekawa i agitująca za tworzeniem spółdzielni produkcyjnych. „Tak więc zalew czytelnika książkami o tematyce produkcyjnej i tłumaczeniami $z$ literatury radzieckiej - twierdzil jeden $z$ nauczycieli wiejskich - zamiast lansowanego przez administratorów od kultury upowszechnienia czytelnictwa i wychowania obywateli w nowym duchu - wywołał skutek wręcz odwrotny"; wieś czytała coraz mniej ${ }^{61}$.

Ten końcowy pesymistyczny wniosek wydaje się sformułowany nieco na wyrost. $Z$ pewnością można postawić tezę, że czytelnictwo na wsi wzrastało w dużym stopniu dzięki celowym akcjom państwowym, przy użyciu administracyjnego nakazu, a niekoniecznie wynikało ze spontanicznego zainteresowania zwłaszcza dorosłych mieszkańców wsi, zniechęconych propagandowym charakterem proponowanych im księgozbiorów. Stwierdzenie na temat kurczenia się czytelnictwa na wsi wydaje się tym bardziej ryzykowne, że czytelnictwo opierało się nie tylko o księgozbiory bibliotek publicznych. W latach pięćdziesiątych nadal - przynajmniej w niektórych regionach kraju - kontynuowały swą działalność biblioteki parafialne. Wydział Kultury KC PZPR w czerwcu 1953 r. szczególnie ostro piętnował ich pracę w województwie poznańskim: „W bibliotekach parafialnych są szczególnie zaśmiecone księgozbiory. Wypożycza się książki szkodliwe, często jeszcze wrogie, które zostały dawno wycofane w bibliotekach publicznych”. Miały one rozchodzić się „systemem łań-

młodzież stanowią lektury szkolne, którymi biblioteki publiczne uzupełniają usługi szkolnych bibliotek, a ile pozycji jest istotnym poszerzeniem czytelnictwa obowiązkowego młodzieży, dowodem jej osobiście przeżytych zainteresowań”. Ibidem, k. 4.

${ }^{58}$ J. Kuczyński, Postawy światopogladowe chłopów, Warszawa 1961, s. 60; podobne wnioski - zob. również: S. A. Kondek, Papierowa ..., dz. cyt., s. 68, 131.

${ }^{59}$ AAN, MKS - CZB, 93, k. nlb. (m.in. sprawozdanie dotyczące woj. olsztyńskiego); AAN, MKiS, CZB, 105, T. Stanisz..., dz. cyt., k. nlb.

${ }^{60}$ AAN, MKiS,CZB, 32, Stan czytelnictwa w powiecie płońskim, dz. cyt.; zob. też: AAN, KC PZPR, 237/XVIII-13, Ocena analizy pracy bibliotek województwa kieleckiego, dz. cyt., s. 92.

${ }^{61}$ AZHRL, Pamiętniki nauczycieli (Ankieta z 1958 r.), P-194, Pamiętniki Stanisława Górala i Adama Owsiakowskiego. 
cuszkowym [...] po gromadach" ${ }^{2}$. W województwie białostockim duchowni mieli „podsuwać wrogą literaturę” przez „istniejące w parafiach księgozbiory «Caritas» i prywatne księżowskie" ${ }^{3}$.

Wydaje się jednak, że najważniejszą rolę w rozwoju czytelnictwa wiejskiego pełniły księgozbiory publiczne. Zgodzić się należy ze Stanisławem Siekierskim, który w podsumowaniu swych wywodów dotyczących czytelnictwa książki literackiej na wsi w okresie stalinowskim stwierdził: „Dominowała [...] literatura klasyczna, pozycje narzucone przez szkołę oraz różne systemy edukacji oficjalnej, które docierały zresztą do wsi o wiele rzadziej niż do miast. Był to także jeden $z$ powodów, że zainteresowanie literaturą współczesną okazało się wielokrotnie mniejsze niż w miastach. Zdecydowanie niższą pozycję zajmowała w czytelnictwie wiejskim proza trywialna. Nie było na wsi zasobów tej literatury, nie było także tradycji zdolnych samodzielnie rozwijać tego typu zainteresowania. Czytelnictwo wiejskie miało więc wszelkie znamiona czytelnictwa elementarnego. Kształtowała je literatura klasyczna, a szkoła utrwalała tradycyjny stosunek do literatury jako źródła poznania świata i innych kultur"

Przedstawione ustalenia, oparte o rzadko wykorzystywane przez badaczy materiały źródłowe, nieźle, jak sądzę dokumentują tytułową tezę o politycznych uwikłaniach funkcjonowania książki i czytelnictwa na wsi w latach 1948-1956. Stalinowski projekt również na tym obszarze aktywności społecznej zetknął się $z$ realiami codzienności. Po raz kolejny miało się okazać, że pod wpływem takiego kontaktu zmieniały się co prawda zachowania społeczne, ale kierunek tych zmian nie zawsze był taki, jaki chcieli rządzący. W dużym stopniu wyznaczały je tradycyjne nawyki kulturalne, a te ze swej natury poddawały się modyfikacjom niezwykle trudno.

\footnotetext{
${ }^{62}$ AAN, KC PZPR, 237/XVIII-13, Analiza pracy bibliotek i czytelnictwa głownie w pionie państwowym na terenie województwa poznańskiego, Poznań 2 VI 1953, k. 273.

${ }^{63}$ AAN, KC PZPR, 237/XVIII-13, Analiza pracy bibliotek w pionie państwowym na terenie województwa białostockiego [1953], k. 30-31.

${ }^{64}$ S. Siekierski, Książka literacka. Potrzeby społeczne i ich realizacja w latach 1944-1986, Warszawa 1992, s. 108.
} 